\title{
F $\mathbb{R} \mathbb{H}$ WRigley, M B, BS, FR C P (C) $\uparrow$
}

STOKES-ADAMS attacks have been recognized for ovel 100 years and onginally were noticed to consist of attacks of syncope occuiring in patients with an abnormally slow pulse Over the past 10 years or so, considerable improvement in our knowledge of the mechanism of these attacks has evolved, together with the development of new methods of treatment for the attacks and for the underlying disease One form of treatment involves operation and the insertion of an artificial pacemaker Consequently, in the last $2 \frac{1}{2}$ years, 26 anaesthetics have been administered at the Royal Victoria Hospital to 14 patients with StokesAdams disease Moreover, most of these patients belong to an older age group, and with an increased life expectancy, they are likely to be presented for operation unrelated to their primary disease, e $g$ bowel obstruction It is the purpose of this paper, therefore, to discuss certain aspects of the disease of significance to anaesthelasts, and to record some of our experience with these 14 cases

\section{The Disease}

Charactenstically the disease is manifested by periodic attacks of loss of consciousness recurring at varying intervals of time, and caused by a cardiac arrhythmia

A sufficient number of cases have now been montored during an attack, both at this hospital and elsewhere, ${ }^{1}$ to classify the types of arrhythmia which cause syncope Most attacks are due to paroxysmal ventricular asystole, but a smaller proportion of attacks are due to paroxysmal ventricular fibrillation or to ventricular tachycardia Most patients appear to develop one type of arrhythmia and adhere to 1t, but, occasionally, a patent will manifest all three arrhythmias at different times, and there is one such case in our series

The type of rhythm occurring between attacks is interesting Portal's group from London, England, ${ }^{1}$ report 19 cases in which 10 had complete heart block and 9 had varying degrees of atrioventricular dissociation, 16 of their patients had right bundle branch block of the 14 patients treated here, at least 5 were in sinus rhythm at the time the attacks were occurning, while 8 were in complete heart block Three of the cases normally in sinus rhythm were found to have bouts of complete block occurring spontaneously 'From the anaesthetist's standpoint, the presence of sinus rhythm does not preclude the possibility that StokesAdams attacks may occur at a subsequent time

"Presented at a meeting of the Quebec Division, Canadian Anaesthetssts' Society, on October 19,1983

tDepartment of Anaesthesia, Royal Victona Hospical, Montreal 


\section{Treatment}

In the long-term management of these cases the cardiologist's aim is to keep the heart rate up, for it has been found that by so doing, one can prevent attacks of asystole, ventricular fibrillation, or tachycardia from occurring ${ }^{2}$ Of the various drugs which have been used to achieve this aim, isopropylnoradrenaline and adrenaline have had the most success They are by no means successful in all cases, or completely reliable in those cases which do respond This moderate degree of success often requires the administration of the drugs by intravenous drip, which is not a sutable means for prolonged administration ${ }^{\text {i } 4}$

For this reason, various electrical methods of maintaning the heart rate at a zeasonable level have been devised The electrical stumul can be applied to the skin of the chest wall, ${ }^{5}$ but voltages required tend to be high, skin burns are produced, the patient often complains of pain, and each stimulus causes contracthon of the pectoral muscles Percutaneous electrodes ${ }^{6}$ may be passed through the chest wall to stimulate the myocardıum, but this method carries the danger of blind myocardial puncture, producing haemopericardium Furman et al ${ }^{7}$ overcame this difficulty by introducing an electiode catheter through either the nght exteinal jugular vein or the right brachial vein into the inght ventricle, under fluoroscopic control They found it possible to pace the heart with very low voltages and could even maintain the system for several months The disadvantages of this method include the necessity of passing a wire through the skin with the associated problem of the occurrence of infection Chardack ${ }^{8}$ and others $^{19}$ have developed a compact transistonzed pacemaker unit with a battery life of 5 years, which can be implanted in the subcutaneous tissues of the anterior abdominal wall and connected by wires to two electiodes sewn into the anterior wall of the ventricles In thıs way all the apparatus is contaned within the body Thoractomy is necessary to insert the electiodes, and if the apparatus needs repair, surgery is necessary to effect this.

It is at this point that we need to examme the problems which may be encountered in administermg an anaesthetic to these patients

\section{Precperativj Preparation}

The first problem is that Stokes-Adanns attacks may occur durng the course of anaesthesia Vandam and McLemore ${ }^{10}$ studied 21 patients who had complete heart block at the time of operation, 12, of these cases had Stokes-Adams attacks prior to operation, and, of these 12,5 suffered circulatory arrest during the course of their anaesthetics There was only 1 case of crrculatory arnest in the group which had not had Stokes-Adams attacks prior to operation, and this was probably a toxic reaction to caudally administered local anaesthetic In 3 of the 5 cases of circulatory arrest, the attacks occurred more than once during the operation At least 2 of these cases were in sinus rhythm at the start of anaesthesia Hodges $^{11}$ reports on an 80 -year-old man who was operated upon for intestinal obstruction $H$ He had a six-year history of complete heart block, and durng the counse of anaesthesia, there were very many attacks of asystole, one 
was even thought to have been precipitated by inflation with oxygen Two attacks of asystole occurring in an 80-year-old man under anaesthesia for treatment of burns probably sustamed in a fall during a Stokes-Adams attack are reported by Ross ${ }^{12} \mathrm{Zoll}^{13}$ and Howat ${ }^{14}$ remark upon the trequency of StokesAdams attacks occurring in patients undergoing operation for the insertion of an implantable subcutaneous pacemaker, when these patients are not being electn cally paced prior to induction of anaesthesia The author has personally witnessed an episode of asystole occurring after intubation in these circumstances

The second problem associated with these patients is the fact that the majority of them are in an older age group and are likely to have some degree of myocardial disease, in fact it is very likely that their Stokes Adams attacks are due to the disease invading the conductung mechanism of the heart If these patients are in complete heart block, the combination of a poor myocardium and a slow rate may be sufficient to precipitate congestive cardiac fallure Indeed, control of the congestive farlure may not be possible until the heart tate is raised This is due to the fact that the diseased myocardium cannot increase its stioke volume sufficiently to maintain cardiac output at the slower rate Johnson et al ${ }^{15}$ have shown how a patient with a complete heart block in caidıac fallure raised cardiac output in response to increasing the rate of an electrical pacemaker

In order to avoid Stokes-Adams attacks during the course of anaesthesia in patients with complete heart block, and in order to improve cardiac output in a patent with myocardial disease, it is essential to raise the heart rate to the order of 70 prior to the induction of anaesthesia, and to maintain it at this level The unreliability of drugs in achieving this end has already been noted The only way of ensuring a constant rate of this order throughout anaesthesia is to pace the heart electrically It has therefore been the practice here (as in several other institutions ${ }^{1,16} 17$ to insert an electrode catheter under fluoroscopic control through a vein into the right ventricle as previously described Not only will this protect the patient from attacks of asystole, but it has been shown that pacing the heart at a rate of 60-90 is equally effective in protecting the patient from StokesAdams altacks due to paroxysmal ventricular fibrillation or tachycardia Those patients with a history of Stokes-Adams attacks who come to operation in sinus rhythm need to be prepared in a similar manner There are several of the patients in this series who are normally in sinus rhythm and who have had subcutaneous pacemakers implanted Competition between the patient's own sinus pacemaker and the mplanted electrical pacemaker does not seem to present any problems apart from causing an irregular pulse when the patient's sinus is functioning

The short-term use of the electrode catheter now seems to be free from any great danger, with one exception Many authors ${ }^{18} 1920$ have drawn attention to the dangers of inducing ventricular fibrillation with faulty electrical equipment when an electrode is present in the ventricle Small unsuspected electrical leaks from monitors or electrocardiagraphs will find their way to ground through the indifferent electrode of a bipolar electrode catheter, or through a unipolar electrode if this is connected to the indifferent (grounded) terminal of the pacemaker The use of a common ground attached to all electrical equipment will help to elmminate the danger, as also will the use of a transistorized pacemaker 
free from mains or ground connections The indifferent (grounded) electrode of a unipolar system should be connected to the skin, allowing any current leak to run to ground through this lead A case of ventricular fibrillation which occurred when using an electric soldering uron to repair an electrode catheter in situ has been reported from this hospital, ${ }^{21}$ and this was due to a very small mains leak in the tool

Several authors ${ }^{1011} 12$ have analysed the predisposing causes of Stokes-Adams attacks occuring under anaesthesia The type of premedication, mode of induction, and the agents used for mantenance have all been examined Intubation and intra-abdominal mampulation, in particular, appear to be stımulı likely to trigger an attack It is, however, not possible to predict with any certainty what stumuli will, or will not, cause an attack On the other hand, it is possible to predict with some certainty that attacks are not likely to occur when the patient has been presented for anaesthesia with an electrode catheter already in place driving the ventricles at a rate of about 70 per minute

\section{ANALSTHISIA}

The seires of cases operated upon at this hospital compises 14 patients who have had 26 general anaesthetics Implantable pacemakers were inserted into all of them and subsequent anaesthesia has been required to rectify faults of one sort or another occurning in the onginal unit One patient had hus pacemaker implanted under general anaesthesia and then required three more general anaesthetics to service the machine Another patient had three general anaesthetics on account of his pacemaker and then had a bowel resection under epidural anaesthesia, followed by two more laparotomies under general anaesthesia. Durng these latter two procedures lhis implanted pacemaker kept him out of trouble from Stokes-Adams attacks One patient had a Bartholin's cyst removed under local anaesthesia and another a bronchoscopy after they had had pacemakers implanted Had the invitation been extended, a general anaesthetic would have been administered with little trepıdation, since their implanted pacemakers were working well at that ime

In only three of these operations was an electrode catheter not inserted prior to operation Unfortunately for the purposes of this paper, anaesthesia proceeded uneventfully in each of them On a fourth occasion the electrode catheter was found to be unreliable because of position sensitivity On another occasion the electrode catheter was in place but not switched on until sinus bradycardia and hypotension developed

Anaesthetic techniques were those in common use for thor acotomy for other diseases The method of induction chosen was usually oxygen followed by thiopentone, followed by succinylcholine and intubation, but there were variations on this theme down to complete exclusion of thiopentone in one case Maintenance was usually nitrous oxide with $d$-tubocuranne used to provide muscle relaxation though fluothane was also used quite frequently When indicated, reversal of the neuromuscular block with atropine and prostigmine was accomplished without event, as would be expected in a patient whose heart is being electrically paced 
Very few problems were encountered Hypotension of a mild degree occurred in several cases There was one death 10 days postoperatively, probably due to acute myocardial infarction

\section{SUMMARY}

Fourteen patients with a history of Stokes-Adams disease have received in all 26 anaesthetics, mostly for the implantation of an artificial pacemaker There is a consıderable danger that Stokes-Adams attacks may occur during the course of anaesthesia and, therefore, it is considered important to pace the heart artificially with an intravenous electrode catheter pror to the induction of anaesthesia

The main danger of the electrode catheter is that minor current leaks from other apparatus (such as an EKG machine) may run to ground through the catheter and cause ventricular fibrillation

The anaesthetic techniques employed in these cases were varied and were those in current use for other thoracotomies Few problems were encountered during the course of these anaesthetics, and this is attributed to the fact that in most of the patients the heart rate was controlled prior to the induction of anaesthesia by means of an artificial pacemaker

\section{RÉSUMÉ}

Quatorze malades, souffrant de la maladie de Stokes-Adams, ont subı en tout 26 anesthésies, la plupart pour l'implantation d'un appareil dont la fonction est d'assurer en automatisme artıficiel Etant donné qu'il existe un giand danger de provoquer des attaques de Stokes-Adams au cours de l'anesthésie 1 s'impose, avant toute anesthésie, de pouvoir stimuler le coeur artificiellement par un cathéter électrode endoveineux

Le principal danger du cathéter électrode est qu'une fraction du courant s'échappe d'un autre apparell (tel, un appareil à électrocardıogramme), se dırıge vers la terre par le cathéter et provoque une fibrillation ventricularre

Chez ces malades, nous avons employé les mêmes technıques anesthésıques variées que nous employons pour les autres thoracotomes Au cours de ces anesthésies, nous n'avons pas eu de problèmes et nous attribuons cela au fait que, chez la plupart des malades, le rythme cardiaque était sous contıôle avant l'ınduction de l'anesthésıe grâce à l'appareıl quı assure unl automatısme artıficiel

\section{REFERENCES}

1 Portal, R W, Davies, J G, Leatham, A, \& Siddons, A H M Artificial Pacing for Heart Block Lancet 111369 ( 1962 )

2 Zoll, P M, Linenthal, A J, \& Zarsky, L R N Ventricular Fibrillation Treatment and Prevention by External Electric Currents New Engl J Med 262105 (1960)

3 Zoll, P M, Linenthal, A J, Gibson, W, Paul, M H, \& Norman, L $\mathbf{R}$ Intravenous Drug Therapy of Stokes-Adams Disease Curculation 17325 (1958)

4 Linenthal, A J \& Zoll, P M Prevention of Ventricular Tachycardia and Fibrillation by Intravenous Isoproterenol and Epinephrne Circulation 275 (1963)

5 Zoll, P M, Linenthal, A J, \& Norman, L R Treatment of Stokes-Adams Disease by External Electnc Stımulation of the Heart Circulation 9482 (1954) 
6 Thevenet, A, Hodges, P C, \& Lmlefiet, C W The Use of a Myocardial Electrode Inserted Percutaneously for Control of / Complete Atnoventncular Block by an Artificial Pacemaker Dis Chest 34 621 (1958)

7 Furman, S, Schwedel, J B, Robinson G, \& Hurwitt, E S Use of an Intracardac Pacemaker in the Control of Heart Block Suigery 4998 (1961)

8 Chardack, W M, Gage, a A, Schimert, G, Thomson, N B, Sanford, C E, \& Greatbach, W Two Years Clinical Expenence with the Implantable Pacemaker for Complete Heart Block Dis Chest 43225 (1963)

9 Landergren, J Notes on the Use of the Artficial Pacemaker for Complete Heart Block and Stokes-Adams Syndrome Acta Chy Scand 124198 (1962)

10 Vandam, L \& McLemone, G A Curculatory Arrest in Patients with Complete Heart Block durng Anaesthessa and Surgery Ann Intern Med 47518 (1957)

11 Hodges, R J H, Wirzeman, R A \& Leigh, A M Multuple Stokes-Adams Episodes durng Anaesthesia Bnt Med J I 625 (1957)

12 Ross, E D General Anaesthesia in Complete Heart Block Bnt J Anaesth 34102 (1962)

13 Zoli, $\mathbf{P}$ M, Frank, H A, Zarsky, L N , Linenthal, A J, \& Belgard, A $\mathbf{H}$ LongTerm Electric Stımulation of the Heart for Stokes-Adams Disease Ann Surg 154330 (1961)

14 Howat, D D C Anaesthesia for the Insertion of Indwelling Artificial Pacemakers Lancet 1855 (1963)

15 Johnson, A L, Klassen, G A, McGregor, M, \& Dobell, A R C Longe-Term Electncal Strmulation of the Heart in Stokes-Adams Disease Canad M A J 89683 (1963)

16 Zucher, I R, Parsonnet, V, Gilbert, L, \& Asa, M Dipolar Electrode in Heart Block J A M A 184549 (1963)

17 DeSANCtIS,, $\mathrm{R}$ W Short-Term Use of Intravenous Electrode in Heart Block J A M A 184544 (1963)

18 Smbons, A H M Long-Term Artificial Cardiac Pacing Expenence in Adults with Heart Block Ann Roy Coll Surg Engl 3222 (1963)

19 Noordijx, J A, OEY, F T I, \& TEBra, W Myocardial Electrodes and the Danger of Ventricular Fibrillation Lancet 1975 (1961)

20 Mody, S M \& Richings, M Ventricular Fibrillation Resulting from Electrocution durnng Cardrac Cathetersation Lancet $n^{\circ} 698$ (1962)

21 Pengeldy, L D \& Klassen, G A Myocardial Electrodes and the Danger of Ventrcular Fibrillation Lancet a 1234 (1961) 